\title{
Exceptionally Stable Ozonides. Influence of Methyl Substituents on the Course of Cyclopentene Ozonolyses and on the Reactivities of Ozonides
}

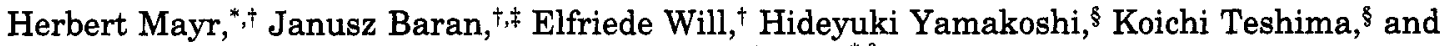 \\ Masatomo Nojima*, \\ Institut für Organische Chemie, Technische Hochschule Darmstadt, 64287 Darmstadt, Germany, and \\ Chemical Process Engineering, Faculty of Engineering, Osaka University, Suita, Osaka 565, Japan
}

Received March 8, $1994^{\otimes}$

\begin{abstract}
Ozonolyses of 1,2,3,3,4,4,5,5-octamethyl- (1a), 1,2,3,3,4,4,5-heptamethyl- (1b), and 1,2,3,3,4,4hexamethyl cyclopentenes (1c) in methanol did not yield the ordinary hemiperacetals but gave the corresponding ozonides $6 \mathbf{a}-\mathbf{c}$ instead. The ozonides $6 \mathbf{a}, \mathbf{b}$ were extremely stable and remained intact even when refluxed with triphenylphosphine in tetrahydrofuran. Cycloreversion of the primary ozonides from unsymmetrically substituted 1,2,3,3-tetramethylcyclopentene (1d) and 1,5,5-trimethylcyclopentene $(\mathbf{1 g})$ was highly regioselective to yield the intermediate $\omega$-oxo carbonyl oxides with the geminal methyl groups remote from the carbonyl oxide groups.
\end{abstract}

The basic mechanism that describes the ozonolysis of an alkene to produce a 1,2,4-trioxolane (secondary ozonide) evolved during the 1950 's and is known as the Criegee mechanism. ${ }^{1}$ It consists of three steps. The first step is a $[3+2]$ cycloaddition reaction of ozone with the alkene leading to formation of a primary ozonide $(1,2,3$ trioxolane). The second is a cycloreversion process of the primary ozonide to provide the transient carbonyl oxide and a stable carbonyl compound, which may proceed in two different ways in the case of unsymmetrically substituted alkenes. Finally, recombination of the carbonyl oxide and the carbonyl compound gives the 1,2,4trioxolane. In alcohols, however, the carbonyl oxide is generally captured by the solvent to yield the corresponding hemiperacetals. ${ }^{1}$ We report now that in ozonolyses of highly methylated cyclopentenes the methyl substituents exert a remarkable influence on the course of the reaction and also on the reactivity of the resulting ozonides toward triphenylphosphine.

\section{Results and Discussion}

Ozonolysis of Highly Methylated Cyclopentenes. Ozonolyses of octamethylcyclopentene (1a) in ether as well as in $\mathrm{CF}_{3} \mathrm{CH}_{2} \mathrm{OH} / \mathrm{CH}_{2} \mathrm{Cl}_{2}(1: 4$, v/v) or $\mathrm{MeOH} / \mathrm{ether}$ $(1: 2, \mathrm{v} / \mathrm{v})$ gave the corresponding ozonide $6 \mathbf{a}$ in isolated yields of 68-72\%; no evidence for the formation of the corresponding epoxide $3 \mathbf{a}^{2 a}$ or its sequential products such as octamethylcyclopentanon $e^{2 \mathrm{~b}}$ was obtained (Scheme 1 ). The structure of the monoozonide $\mathbf{6 a}$ was unambiguously determined by X-ray analysis. ${ }^{3}$

In analogy to the ozonolysis of compound 1a, Criegee and co-workers ${ }^{4}$ reported that the reaction of 1,2 -dimethylcyclopentene (1e) with ozone in pentane results in

\footnotetext{
† Technische Hochachule Darmstadt.

\$ Present address: Institute of Fundamental Chemistry, Technical University of Szczecin, Al. Plastów 42, PL-71065, Szczecin, Poland.

$\$$ Osaka University.

- Abstract published in Advance ACS Abstracts, July 15, 1994.

(1) (a) Bailey, P. S. Ozonation in Organic Chemistry; Academic Press: New York, 1978; Vol. 1; 1982; Vol. 2. (b) Bunnelle, W. H. Chem. Rev. 1991, 91, 335. (c) McCullough, K. J.; Nojima, M. In Organic Peroxides; Ando, W., Ed.; Wiley: New York, 1992.

(2) (a) Bailey, P. S.; Hwang, H. H.; Chiang, C.-Y. J. Org. Chem. 1985 , 50, 231. (b) Mayr, H.; Koschinsky, R.; Will, E.; Bäuml, E. J. Org. Chem. $1987,52,1342$.

(3) Jerzykiewicz, L. B.; Dziewońska-Baran, D.; Baran, J.; Lis, T. Acta Crystallogr. 1993, C49, 400
}

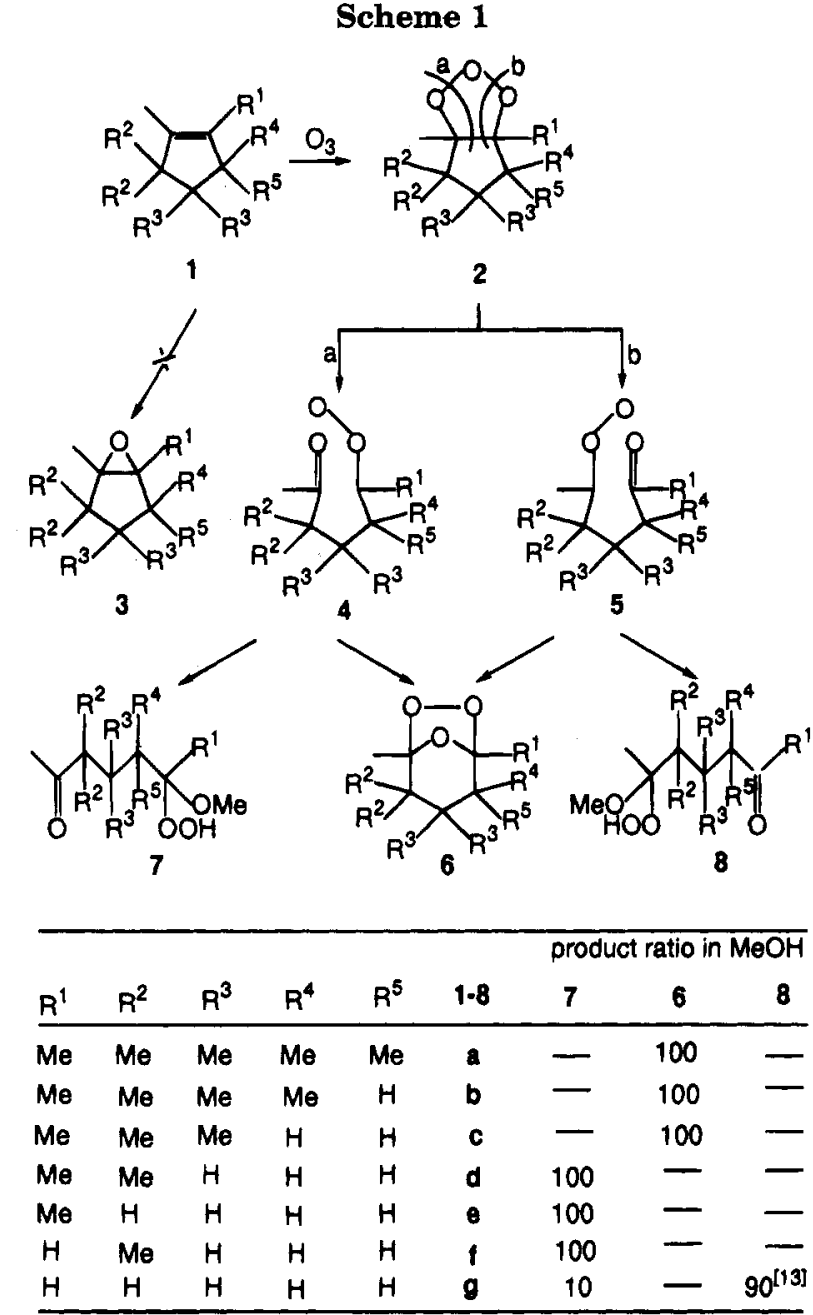

a quantitative formation of the corresponding ozonide $6 \mathbf{e}$. We observed that ozonide 6e was also obtained in ether in $84 \%$ yield. In contrast, capture of the carbonyl oxide intermediate $4 \mathbf{e}$ by the solvent predominated in methanol, and the expected $\alpha$-methoxyalkyl hydroperoxide $7 e$ was obtained in $86 \%$ yield (Scheme 1).

(4) Criegee, R.; Blust, G.; Lohaus, G. Liebigs Ann. Chem. 1953, 583, 
In order to understand the remarkably different behavior of the carbonyl oxide intermediates, $4 a$ and $4 \mathbf{e}$, toward methanol, we investigated the ozonolyses of 1,2,3,3,4,4,5-heptamethyl- (1b), 1,2,3,3,4,4-hexamethyl(1c), and 1,2,3,3-tetramethyl cyclopentenes (1d) (Scheme 1). Ozonolyses in ether at $-70^{\circ} \mathrm{C}$ gave the corresponding ozonides $6 \mathrm{~b}-\mathrm{d}$ in yields of $75 \%, 72 \%$, and $73 \%$, respectively. Also, in $\mathrm{MeOH}-$ ether $(1: 2, \mathrm{v} / \mathrm{v})$ the reactions of the cyclopentenes $1 \mathrm{~b}$ and $1 \mathrm{c}$ with ozone at $-70{ }^{\circ} \mathrm{C}$ resulted in the formation of ozonides $6 \mathbf{b}(79 \%)$ and $\mathbf{6 c}$ (77\%), respectively. In marked contrast, ozonolysis of tetramethylcyclopentene (1d) under the same conditions led to the formation of the methanol-derived product $\mathbf{7 d}$. The hydroperoxide 7d was labile; however, and evaporation of the solvent was accompanied by partial decomposition to diketone 10d. The ozonolysis of $1 \mathrm{~d}$ was, therefore, performed in $\mathrm{CD}_{3} \mathrm{OD}$ and the ${ }^{1} \mathrm{H}$ - and ${ }^{13} \mathrm{C}-\mathrm{NMR}$ spectra of the $\mathrm{CD}_{3} \mathrm{OD}$ solution obtained in this way indicated the presence of hydroperoxide $\mathbf{7 d}-d_{4}$ as the sole detectable product.

Thus, carbonyl oxide intermediates, $4 \mathbf{a}-\mathbf{c}$ and/or $\mathbf{5 b}, \mathbf{c}$, seem to undergo intramolecular cycloaddition even in methanol, while the sterically less-congested carbonyl oxides 4 d,e can be efficiently captured by the solvent. Of particular interest is the different behavior of the substrates 1c and 1d, which suggests that the presence of the methyl substituents at the 4-position is also indispensable for the formation of ozonide in methanol.

The formation of ozonides $6 \mathrm{a}-\mathbf{c}$ in methanol ${ }^{7,8}$ is explained by the gem-dimethyl effect ${ }^{9}$ which obviously accelerates intramolecular cycloaddition to such an extent that capture of the carbonyl oxide by methanol cannot compete. Two modes of cycloreversion of the unsymmetrically substituted primary ozonide $2 \mathbf{d}$ are possible. Each pathway leads to a different carbonyl oxide, 4d (path a in Scheme 1) or 5d (path b in Scheme 1). Exclusive formation of the methanol-derived product 7d from 1d, however, implies that presence of two methyl groups in one allylic position of the substrate olefin causes a regioselective cleavage of the primary ozonide $\mathbf{2 d}$ to give the carbonyl oxide intermediate $4 \mathrm{~d}$ with the geminal methyl groups remote from the carbonyl oxide fragment. ${ }^{10,11}$

In order to estimate the extent of the directive effect of the allylic gem-dimethyl group on the regioselectivity of the cleavage of the primary ozonide, we studied the ozonolysis of 1,5,5-trimethylcyclopentene (1f). It is wellestablished that trialkyl-substituted alkenes react with ozone to produce an aldehyde and a ketone $O$-oxide predominantly, since electron-donating alkyl substituents stabilize the carbonyl oxide..$^{1 \mathrm{a}, 12}$ Consistent with this, Griesbaum and Kiesel ${ }^{13}$ have found that ozonolysis of 1-methylcyclopentene (1g) in methanol proceeds mainly

(5) Consistent with this, ozonolysis of 3,4-dimethyl-2,5-dihydrothiophene 1,1-dioxide in methanol gives the corresponding hemiperacetal in high yield. 6

(6) Criegee, R.; Lohaus, G. Liebigs Ann. Chem. 1958, 583, 12.

(7) A similar trend has been observed for the ozonolyses of highlysubstituted cyclobutene derivatives, hexamethyldewarbenzene, ${ }^{8}$ and 3,3,4-trisubstituted 1,2-diphenylcyclobutenes in methanol. $8 \mathrm{~b}$

(8) (a) Junker, H.-N.; Schäfer, W.; Niedenbrück, H. Chem. Ber. 1967, 100, 2508. (b) Reinhardt, H. G.; Doorakian, G. A.; Freedman, H. H. J' Am. Chem. Soc. 1868, 90, 5934 .

(9) (a) Smith, S. W.; Newman, M. S. J. Am. Chem. Soc. 1968, 90, 1249, 1253. (b) Capon, B.; McManus, S. P. Neighboring Group Participation; Plenum: New York, 1976.

(10) Criegee reported a similar directing effect of the methyl groups during ozonolysis of 1,2,3,3-tetramethyl-4-acetylcyclohexene. 11a

(11) (a) Criegee, R. Chem. Ber. 1975, 108, 743. (b) For the steric effects see also: Griesbaum, K; Volpp, W. Chem. Ber. 1988, 121, 1795.
Scheme 2

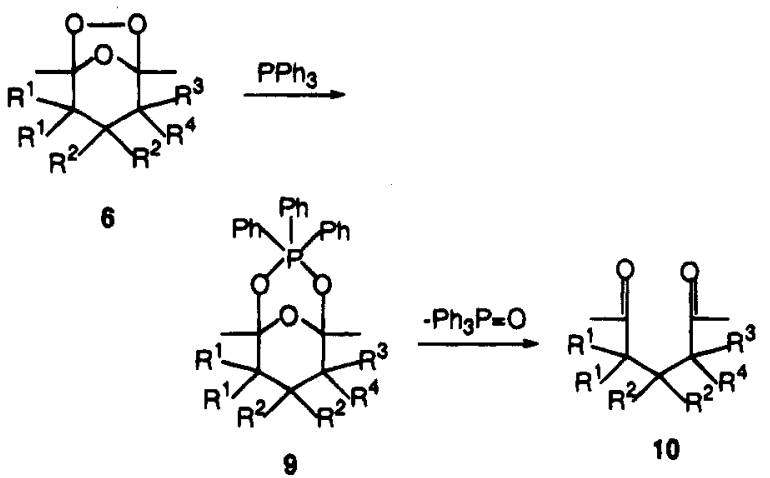

$$
\begin{array}{ll}
\text { a; } R^{1}=R^{2}=R^{3}=R^{4}=M e & \text { b; } R^{1}=R^{2}=R^{3}=M e, R^{4}=H \\
\text { c; } R^{1}=R^{2}=M e, R^{3}=R^{4}=H & \text { d; } R^{1}=M e, R^{2}=R^{3}=R^{4}=H \\
\text { e; } R^{1}=R^{2}=R^{3}=R^{4}=H &
\end{array}
$$

by the ketone $O$-oxide $5 \mathbf{g}$ (the ratio of contribution of $\mathbf{4 g}$ and $5 \mathrm{~g}$ is ca. 1:9) (Scheme 1). Thus, in the case of compound 1f, the electronic effect of the methyl substituent at the 1-position and the steric effect of the geminal methyl groups at the 5-position should direct in opposite sense and both of the possible carbonyl oxide intermediates, $\mathbf{4 f}$ and $\mathbf{5 f}$, may competitively participate.

The sole isolable product obtained from the ozonolysis of $1 f$ in $\mathrm{MeOH}$-ether was hydroperoxide $7 \mathbf{f}$, however, which is derived from capture of $4 \mathrm{f}$ by methanol (Scheme 1). It is thus suggested that in the cycloreversion of the primary ozonide 2f, the directive effect of the allylic methyl groups is still decisive, thereby producing the lesshindered carbonyl oxide $4 f$ predominantly. However, the reason for this strong directive effect of the allylic methyl substituents is obscure.

Reduction of Cyclopentene Ozonides. Ozonides are well known to be easily reduced by various reductants. ${ }^{1}$ Treatment of ozonide $6 \mathrm{a}$ with $\mathrm{Zn}$ /acetic acid in ether at $20^{\circ} \mathrm{C}^{14}$ resulted in the recovery of ozonide $6 \mathrm{a}$. In refluxing ether, however, ozonide $6 \mathbf{a}$ was efficiently reduced to diketone $10 \mathrm{a}$ with $\mathrm{Zn} / \mathrm{CH}_{3} \mathrm{CO}_{2} \mathrm{H}$ during $3 \mathrm{~h}$. Under the latter conditions, the diketones $10 \mathrm{~b}, \mathrm{c}$ were obtained from the ozonides $\mathbf{6 b}, \mathbf{c}$. Hydrogenation catalyzed by palladium on activated carbon under atmospheric pressure gave also diketone 10a quantitatively.

Surprisingly, ozonides $\mathbf{6 a}, \mathbf{b}$ could not be reduced by triphenylphosphine in $\mathrm{CDCl}_{3}$ at $20^{\circ} \mathrm{C}$, in refluxing ether during several days, or in refluxing tetrahydrofuran. Under similar conditions the sterically-congested monoozonide from hexamethyldewarbenzene and also 1,2,3triphenylindene ozonide were reduced to the corresponding diketones. Compounds $\mathbf{6 a , b}$ are, therefore, the least reactive ozonides toward triphenylphosphine presently known.

In contrast to $6 \mathbf{a}, \mathbf{b}$, hexamethylcyclopentene ozonide (6c) was efficiently reduced to the corresponding diketone $10 \mathrm{c}$ by triphenylphosphine in refluxing tetrahydrofuran. The reaction of the less-hindered ozonides $\mathbf{6 d , e}$ with triphenylphosphine was very fast; in $\mathrm{CDCl}_{3}$ the ozonides 6d,e were rapidly deoxygenated at $20^{\circ} \mathrm{C}$ to give the corresponding diketones 10d,e (Scheme 2). Competitive

(12) (a) Bunnelle, W. H.; Isbell, T. A. J. Org. Chem. 1992, 57, 729. (b) Sugiyama, T.; Yamakoshi, H.; Nojima, M. J. Org. Chem. 1993, 58, 4212.

(13) Griesbaum, K.; Kiesel, G. Chem. Ber. 1989, 122, 145.

(14) Harries, C.; Haarmann, R. Chem. Ber. 1915, 48, 32. 
Scheme 3

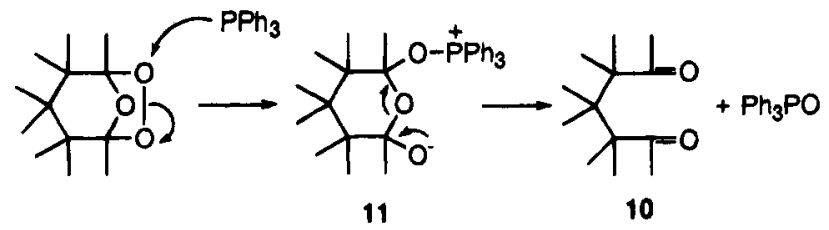

Table 1. Heats of Formation of Ozonides 6a-e, Phosphoranes 9a-e, and 1,6-Dipoles 11a-e Calculated by PM3 Semiempirical Method (kcal/mol) ${ }^{a}$

\begin{tabular}{llllcc}
\hline & & & & $\Delta H_{\mathrm{r}}$ & $\Delta H_{\mathrm{r}}$ \\
& $\Delta H_{\mathrm{f}}(\mathbf{6})$ & $\Delta H_{\mathrm{f}}(\mathbf{9})$ & $\Delta H_{\mathrm{f}}(\mathbf{1 1})$ & $\mathbf{6}+\mathrm{Ph}_{3} \mathrm{P}-\mathbf{9}$ & $\mathbf{6}+\mathrm{Ph}_{3} \mathrm{P} \rightarrow \mathbf{1 1}$ \\
\hline $\mathbf{a}$ & -96.82 & -57.57 & -27.98 & -50.78 & -21.19 \\
b & -96.20 & -57.46 & -28.58 & -51.29 & -22.41 \\
c & -94.93 & -58.27 & -32.47 & -53.37 & -27.57 \\
d & -88.45 & -56.39 & -29.28 & -57.97 & -30.86 \\
e & -81.78 & -49.26 & -22.35 & -57.51 & -30.60
\end{tabular}

a The heat of formation of triphenylphosphine was $90.03 \mathrm{kcal}$ mol.

experiments showed the reactivity of ozonides toward triphenylphosphine to follow the sequence 1a,1b $<\mathbf{1 c}<$ 1d,1e.

For the deoxygenation of ozonides with triphenylphosphine the mechanisms depicted in Schemes $2^{15}$ and $3^{16}$ are conceivable. According to semiempirical PM3 calculations the reaction of triphenylphosphine with ozonide 6 is exothermic to give either the phosphorane 9 or the zwitterionic intermediate 11. Since the calculations refer to the gas phase, the difference of enthalpy calculated for the first step of the two different pathways is irrelevant, as the solvent will considerably stabilize the dipolar intermediate 11 relative to 9 . Table 1 shows, however, that for both mechanisms a decrease of exothermicity with increasing number of methyl groups is calculated. The differences in reaction enthalpies thus reflect the relative heights of the barriers of the reductions with triphenylphosphine.

Conclusion. The stabilities of 6,7,8-trioxabicyclo[3.2.1]octanes 6 (cyclopentene ozonides) are highly increased by methyl substitution as seen from their rates of reduction. The gem-dimethyl effect is suggested to be responsible for fast cyclization of the highly-methylated intermediate carbonyl oxides and the failure to trap $4 a-c$ or $\mathbf{5 b}, \mathbf{c}$ by methanol. The semiempirical calculations suggest that the increase of conformational strain during lengthening the $\mathrm{O}-\mathrm{O}$ bond is greater in the highly methyl-substituted compounds 6. As a result, the ozonides $6 \mathbf{a}$ and $\mathbf{6 b}$ are so stable that they do not react even with triphenylphosphine in refluxing THF.

\section{Experimental Section}

General. ${ }^{1} \mathrm{H}$ and ${ }^{13} \mathrm{C}$ NMR spectra were obtained in $\mathrm{CDCl}_{3}$ (unless otherwise noted) with $\mathrm{SiMe}_{4}$ as standard. 1,2,3,3,4,4,5,5Octamethylcyclopentene (1a), ${ }^{17} 1,2,3,3,4,4,5$-heptamethylcyclopentene (1b), ${ }^{17} 1,2,3,3,4,4$-hexamethylcyclopentene (1c) $)^{17}$ 1,2,3,3-tetramethylcyclopentene (1d), ${ }^{18}$ 1,2-dimethylcyclopentene (1e) (in admixture with $7 \%$ of 2,3 -dimethylcyclopentene), ${ }^{19}$

(15) (a) Carles, J.; Fliszär, S. Can. J. Chem. 1970, 48, 1309. (b) In this connection, the corresponding phosphorane is certainly produced in the reduction of dioxetane with triphenylphosphine. On warming, the phosphorane eliminates the phosphine oxide to yield the epoxide: Bartlett, P. D.; Baumstark, A. L.; Landis, M. E.; Lerman, C. L. J. Am. Chem. Soc. 1974, 96, 5267.

(16) A reviewer has kindly suggested this alternative mechanism.

(17) Klein, H.; Mayr, H. Angew. Chem., Int. Ed. Engl. 1981, 20, 1027. (18) Horn, D. E.; Krapcho, A. P.; Grenon, B. Y. J. Org. Chem. 1979, 44,454 . and 1,5,5-trimethylcyclopentene (1f), ${ }^{20}$ were prepared by the reported methods. The method of ozonolysis was previously described. $12 \mathrm{~b}$

Ozonolyses of Cyclopentenes $1 \mathrm{a}-\mathrm{c}$ in $\mathrm{MeOH}-\mathrm{Ether}$. Ozonolysis of compound 1a is representative. A MeOH-ether solution $(15 \mathrm{~mL}, 1: 2 \mathrm{v} / \mathrm{v})$ of compound $1 \mathrm{a}(235 \mathrm{mg}, 1.30 \mathrm{mmol})$ was treated with ozone $\left(2.61 \mathrm{mmol}, 2\right.$ equiv) at $-70^{\circ} \mathrm{C}$. After ether $(50 \mathrm{~mL})$ was added, the organic layer was washed with aqueous $\mathrm{NaHCO}_{3}$ and then with saturated brine, and the solvent was evaporated ( $\mathrm{rt}, 15 \mathrm{mmHg}$ ). The ${ }^{1} \mathrm{H}$ NMR spectra of the crude products showed the formation of small amounts of a methanol-derived product $(\delta 3.37)$. The residue was separated by column chromatography (column $2.0 \times 60 \mathrm{~cm}$; $40 \mathrm{~g}$ of silica gel). Elution with ether-hexane (5:95) gave ozonide $6 a$ ( $215 \mathrm{mg}, 72 \%$ yield). Further elution with etherhexane (1:4 to $1: 1$ ) yielded $24 \mathrm{mg}$ of a complex mixture of unidentified products.

1,2,2,3,3,4,4,5-Octamethyl-6,7,8-trioxabicyclo[3.2.1]octane (6a): $\mathrm{mp} 101-103{ }^{\circ} \mathrm{C}$ (from hexane); ${ }^{1} \mathrm{H} \mathrm{NMR}\left(\mathrm{CCl}_{4}\right)$ $\delta 0.79(\mathrm{~s}, 3 \mathrm{H}), 0.90(\mathrm{~s}, 6 \mathrm{H}), 1.08(\mathrm{~s}, 6 \mathrm{H}), 1.18(\mathrm{~s}, 3 \mathrm{H}), 1.38$ (s, $6 \mathrm{H}) ;{ }^{13} \mathrm{C}$ NMR $\delta 17.86,21.98,22.76,24.61,25.31,41.18$, $43.19,114.34$; MS $m / z 228\left(M^{+}\right)$. Anal. Calcd for $\mathrm{C}_{13} \mathrm{H}_{24} \mathrm{O}_{3}$ : C, 68.38; H, 10.60. Found: C, 68.22; H, 10.71 .

1,2,2,3,3,4,5-Heptamethyl-6,7,8-trioxabicyclo[3.2.1]-

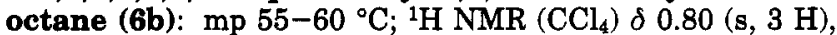
$0.87(\mathrm{~s}, 3 \mathrm{H}), 0.92(\mathrm{~d}, J=7 \mathrm{~Hz}, 3 \mathrm{H}), 0.97(\mathrm{~s}, 3 \mathrm{H}), 1.10$ (s, 3 $\mathrm{H}), 1.35(\mathrm{~s}, 3 \mathrm{H}), 1.38(\mathrm{~s}, 3 \mathrm{H}), 1.78(\mathrm{q}, J=7 \mathrm{~Hz}, 1 \mathrm{H}) ;{ }^{13} \mathrm{C}$ NMR $\delta 11.10,17.88,19.74,19.81,20.10,22.81,25.36,38.92$, 42.68, 43.82, 110.67, 113.98. Anal. Calcd for $\mathrm{C}_{12} \mathrm{H}_{22} \mathrm{O}_{3}$ : C, $67.26 ; \mathrm{H}, 10.35$. Found: C, $66.94, \mathrm{H}, 10.45$.

1,2,2,3,3,5-Hexamethyl-6,7,8-trioxabicyclo[3.2.1]octane (6c): oil; ${ }^{1} \mathrm{H} \mathrm{NMR}\left(\mathrm{CCl}_{4}\right) \delta 0.88(\mathrm{~s}, 3 \mathrm{H}), 0.95(\mathrm{~s}, 3 \mathrm{H})$, $1.04(\mathrm{~s}, 3 \mathrm{H}), 1.37(\mathrm{~s}, 3 \mathrm{H}), 1.50(\mathrm{~s}, 6 \mathrm{H}), 1.63(\mathrm{~d}, J=14 \mathrm{~Hz}, 1$ $\mathrm{H}), 1.93(\mathrm{~d}, J=14 \mathrm{~Hz}, 1 \mathrm{H}) ;{ }^{13} \mathrm{C}$ NMR $\delta 17.67,19.09,21.05$, $22.99,28.02,28.10,35.42,41.57,46.37,108.18,114.29$. Anal. Calcd for $\mathrm{C}_{11} \mathrm{H}_{20} \mathrm{O}_{3}$ : C, 65.97; $\mathrm{H}, 10.06$. Found: $\mathrm{C}, 66.19 ; \mathrm{H}$, 10.10 .

Ozonolysis of 1,2,3,3-Tetramethylcyclopentene (1d) in Ether. A slow stream of ozone ( $4 \mathrm{mmol}$ ) was passed into a solution of $1 \mathrm{~d}(496 \mathrm{mg}, 3.99 \mathrm{mmol})$ in ether $(15 \mathrm{~mL})$ at -70 ${ }^{\circ} \mathrm{C}$. After evaporation of the solvent, ozonide $6 \mathrm{~d}(499 \mathrm{mg}, 73 \%)$ was isolated by column chromatography on silica gel (elution with ether-hexane, 3:97)

1,2,2,5-Tetramethyl-6,7,8-trioxabicyclo[3.2.1]octane (6d): oil; ${ }^{1} \mathrm{H} \mathrm{NMR}\left(\mathrm{CCl}_{4}\right) \delta 0.91(\mathrm{~s}, 3 \mathrm{H}), 1.03(\mathrm{~s}, 3 \mathrm{H}), 1.31(\mathrm{~s}$, $3 \mathrm{H}), 1.38(\mathrm{~s}, 3 \mathrm{H}), 1.5-2.3(\mathrm{~m}, 4 \mathrm{H}) ;{ }^{13} \mathrm{C}$ NMR $\delta 16.47,20.86$, 23.01, 25.26, 31.92, 31.94, 36.62, 108.56, 113.37. Anal. Calcd for $\mathrm{C}_{9} \mathrm{H}_{16} \mathrm{O}_{3}: \mathrm{C}, 62.77 ; \mathrm{H}, 9.36$. Found: $\mathrm{C}, 62.99 ; \mathrm{H}, 9.56$.

Ozonolysis of Compound $1 \mathrm{~d}$ in MeOH-Ether. A slow stream of ozone (1.67 mmol) was passed into a solution of $1 \mathrm{~d}$ (207 $\mathrm{mg}, 1.67 \mathrm{mmol}$ ) in $\mathrm{MeOH}$-ether $(13 \mathrm{~mL}, 10: 3)$ at -70 ${ }^{\circ} \mathrm{C}$. After evaporation of the solvent, the products were separated by column chromatography on silica gel. Elution with ether-hexane (2:3) gave a $2: 1$ mixture of hydroperoxide 7d and diketone 10d (124 mg), which could not be separated from each other.

3,3-Dimethyl-6-hydroperoxy-6-methoxy-2-heptanone (7d) (in admixture with 30\% of diketone 10d): oil; ${ }^{1} \mathrm{H}$ NMR $\left(\mathrm{CCl}_{4}\right) \delta 0.9-1.2(\mathrm{~m}, 4 \mathrm{H}), 1.13(\mathrm{~s}, 3 \mathrm{H}), 1.23(\mathrm{~s}, 3 \mathrm{H}), 1.53(\mathrm{~s}$, $3 \mathrm{H}), 2.13(\mathrm{~s}, 3 \mathrm{H}), 3.23(\mathrm{~s}, 3 \mathrm{H}), 8.98(\mathrm{br} \mathrm{s}, 1 \mathrm{H})$; IR 3600$3100,2960,1690,1360,1200,1100,840 \mathrm{~cm}^{-1}$.

Ozonolysis of Compound $1 \mathrm{~d}$ in $\mathrm{CD}_{3} \mathrm{OD}$. In a NMR tube compound 1d ( $31 \mathrm{mg}, 0.25 \mathrm{mmol}$ ) dissolved in $\mathrm{CD}_{3} \mathrm{OD}(1 \mathrm{~mL}$ ) was treated with 1.2 equiv of ozone at $-70^{\circ} \mathrm{C}$. The ${ }^{1} \mathrm{H}$ - and ${ }^{13} \mathrm{C}$-NMR spectra indicated a quantitative formation of hydroperoxide 7d- $d_{4}:{ }^{1} \mathrm{H}$ NMR $\delta$ 0.9-1.2 $(\mathrm{m}, 4 \mathrm{H}), 1.13(\mathrm{~s}, 3 \mathrm{H})$, $1.27(\mathrm{~s}, 3 \mathrm{H}), 1.57(\mathrm{~s}, 3 \mathrm{H}), 2.13(\mathrm{~s}, 3 \mathrm{H}) ;{ }^{13} \mathrm{C}$ NMR $\delta 20.16$, $25.39,25.60,26.11,32.48,35.79,108.03,217.30$ (the signal attributable to the $\mathrm{CD}_{3} \mathrm{O}$-carbon could not be defined due to the presence of $\left.\mathrm{CD}_{3} \mathrm{OD}\right)$. A solution of triphenylphosphine (100 $\mathrm{mg}, 1.5$ equiv) in $\mathrm{CDCl}_{3}(0.5 \mathrm{~mL})$ was added, and the mixture was kept at room temperature for $1 \mathrm{~h}$. The ${ }^{1} \mathrm{H}$ NMR spectrum indicated a quantitative formation of diketone $10 \mathrm{~d}$, which was

(19) Büchi, G.; Chu, P.-S. Tetrahedron 1981, 37, 4509.

(20) Fadel, A.; Salaün, J. Tetrahedron 1985, 41, 413. 
isolated by column chromatography on silica gel (elution with ether-hexane, 1:1). 3,3-Dimethyl-2,6-heptanedione $(10 \mathrm{~d})^{21}$ was an oil: ${ }^{1} \mathrm{H}$ NMR $\left(\mathrm{CCl}_{4}\right) \delta 1.08(\mathrm{~s}, 6 \mathrm{H}), 1.5-1.9(\mathrm{~m}, 2 \mathrm{H})$, 2.05 (s, $6 \mathrm{H}), 2.1-2.4(\mathrm{~m}, 2 \mathrm{H}) ;{ }^{13} \mathrm{C}$ NMR $\delta 24.21,24.99,29.88$, $32.77,38.92,46.86,208.05,213.33$; IR $1700,1350,1150,1120$ $\mathrm{cm}^{-1}$.

Ozonolysis of 1,2-Dimethylcyclopentene (1e) in Ether. A slow stream of ozone (1 equiv) was passed into an ether solution (15 mL) of 1 e (93\% pure, $205 \mathrm{mg}, 1.98 \mathrm{mmol}$ ) at -70 ${ }^{\circ} \mathrm{C}$. After evaporation of the solvent, the residue was separated by column chromatography on silica gel. Elution with etherhexane (1:9) gave 1,5-dimethyl-6,7,8-trioxabicyclo[3.2.1]octane $(6 \mathrm{e})^{4}$ as an oil ( $\left.241 \mathrm{mg}, 84 \%\right)$ : ' $\mathrm{H}$ NMR $\delta 1.38$ (s, $\left.6 \mathrm{H}\right), 1.5-$ $1.9(\mathrm{~m}, 6 \mathrm{H})$.

Ozonolysis of Compound $1 \mathrm{e}$ in MeOH-Ether. A $\mathrm{MeOH}$-ether solution (15 mL, 1:3) of 1 e $(93 \%$ pure, $192 \mathrm{mg}$, $1.86 \mathrm{mmol}$ ) was treated with 1 equiv of ozone at $-70^{\circ} \mathrm{C}$. After evaporation of the solvent, the residue was separated by column chromatography on silica gel. Elution with etherhexane $(1: 1)$ gave 6-hydroperoxy-6-methoxy-2-heptanone (7e) $(281 \mathrm{mg}, 86 \%)$. Treatment of $7 \mathrm{e}$ with 1 equiv of triphenylphosphine in $\mathrm{CH}_{2} \mathrm{Cl}_{2}$ at $\mathrm{rt}$ for $2 \mathrm{~h}$, followed by column chromatography on silica gel (elution with ether-hexane, 2:3) gave heptane-2,6-dione (10e) (189 mg, $94 \%$ yield). Heptane2,6-dione (10e): $\mathrm{mp} 27-30^{\circ} \mathrm{C}$ (lit. ${ }^{22} \mathrm{mp} \mathrm{29-32}{ }^{\circ} \mathrm{C}$ ); ${ }^{1} \mathrm{H}$ NMR $\delta 1.5-2.0(\mathrm{~m}, 2 \mathrm{H}), 2.05(\mathrm{~s}, 6 \mathrm{H}), 2.2-2.5(\mathrm{~m}, 4 \mathrm{H})$; IR 2930 , $1705,1350,1155,960 \mathrm{~cm}^{-1}$.

6-Hydroperoxy-6-methoxy-2-heptanone (7e): oil; ${ }^{1} \mathrm{H}$ NMR $\delta 1.23(\mathrm{~s}, 3 \mathrm{H}), 1.5-1.9(\mathrm{~m}, 4 \mathrm{H}), 2.10(\mathrm{~s}, 3 \mathrm{H}), 2.2-2.6$ $(\mathrm{m}, 2 \mathrm{H}), 3.24(\mathrm{~s}, 3 \mathrm{H}), 8.33(\mathrm{~s}, 1 \mathrm{H}) ;{ }^{13} \mathrm{C} \mathrm{NMR} \delta 16.86,17.52$ $21.33,32.99,42.31,50.54,108.92,208.63$; IR 3600-3100, 2950, $1700,1365,1100,1060 \mathrm{~cm}^{-1}$. Anal. Calcd for $\mathrm{C}_{8} \mathrm{H}_{16} \mathrm{O}_{4}: \mathrm{C}$, 54.53; H, 9.15. Found: C, 54.28; H, 8.92.

Ozonolysis of 1,5,5-Trimethylcyclopentene (1f) in Ether. A slow stream of ozone was passed into an ether $(15 \mathrm{~mL})$ solution of $1 \mathrm{f}(78 \mathrm{mg}, 0.71 \mathrm{mmol})$ at $-70^{\circ} \mathrm{C}$. After evaporation of the solvent, the residue was separated by column chromatography on silica gel. Elution with ether-hexane (5:95) gave the ozonide $6 f(65 \mathrm{mg}, 58 \%$ ).

1,2,2-Trimethyl-6,7,8-trioxabicyclo[3.2.1]octane (6f): oil ${ }^{1} \mathrm{H} \mathrm{NMR}\left(\mathrm{CCl}_{4}\right) \delta 0.93(\mathrm{~s}, 3 \mathrm{H}), 1.07(\mathrm{~s}, 3 \mathrm{H}), 1.38(\mathrm{~s}, 3 \mathrm{H})$, $1.5-2.3(\mathrm{~m}, 4 \mathrm{H}), 5.58(\mathrm{br} \mathrm{s}, 1 \mathrm{H}) ;{ }^{13} \mathrm{C}$ NMR $\delta 16.15,23.15$, 25.67, 27.81, 30.80, 37.59, 102.62, 112.48. Anal. Calcd for $\mathrm{C}_{8-}$ $\mathrm{H}_{14} \mathrm{O}_{3}$ : C, $60.74 ; \mathrm{H}, 8.92$. Found: $\mathrm{C}, 60.55 ; \mathrm{H}, 9.00$.

Ozonolysis of $1,5,5$-Trimethylcyclopentene (1f) in MeOH-Ether. A slow stream of ozone was passed into a solution of $1 \mathrm{f}(78 \mathrm{mg}, 0.71 \mathrm{mmol})$ in $\mathrm{MeOH}$-ether ( $15 \mathrm{~mL}, 1: 2)$ at $-70^{\circ} \mathrm{C}$. Ether $(50 \mathrm{~mL})$ was added, and the reaction mixture was washed with aqueous $\mathrm{NaHCO}_{3}$ and saturated brine and dried over anhydrous $\mathrm{MgSO}_{4}$. After evaporation of the solvent, the residue was separated by column chromatography on silica gel. Elution with ether-hexane $(2: 3)$ gave the hydroperoxide 7f ( $87 \mathrm{mg}, 64 \%)$.

3,3-Dimethyl-6-hydroperoxy-6-methoxy-2-hexanone (7f): oil: ${ }^{1} \mathrm{H}$ NMR $\left(\mathrm{CCl}_{4}\right) \delta 1.10(\mathrm{~s}, 6 \mathrm{H}), 1.4-1.7(\mathrm{~m}, 4 \mathrm{H}), 2.10$ $(\mathrm{s}, 3 \mathrm{H}), 3.44(\mathrm{~s}, 3 \mathrm{H}), 4.5-4.7(\mathrm{~m}, 1 \mathrm{H}), 9.60(\mathrm{br} \mathrm{s}, 1 \mathrm{H}) ;{ }^{13} \mathrm{C}$ NMR $\delta 24.26,24.79,25.29,27.22,34.23,47.52,56.12,108.62$, 214.85 ; IR $3600-3100,1700,1460,1360,1100 \mathrm{~cm}^{-1}$. Anal. Calcd for $\mathrm{C}_{9} \mathrm{H}_{18} \mathrm{O}_{4}: \mathrm{C}, 56.82 ; \mathrm{H}, 9.54$. Found: $\mathrm{C}, 57.02 ; \mathrm{H}, 9.43$.

Reduction of Ozonides $6 \mathrm{a}-\mathrm{c}$ with $\mathrm{Zn} / \mathrm{CH}_{3} \mathrm{CO}_{2} \mathrm{H}$. The reduction of $6 \mathbf{a}$ is representative. An ether $(10 \mathrm{~mL})$-acetic acid $(2 \mathrm{~mL})$ solution of $6 \mathrm{a}(0.5 \mathrm{~g}, 2.19 \mathrm{mmol})$ and $\mathrm{Zn}(3.0 \mathrm{~g})$ was refluxed for $3 \mathrm{~h}$. After filtration of $\mathrm{Zn}$, the organic layer was washed with water and aqueous $\mathrm{NaHCO}_{3}$, and dried over

(21) Duhamel, P.; Hennequin, L.; Poirier, N.; Poirier, J.-M. Tetrahedron Lett. 1985, 26, 6201.

(22) Crandall, J. K.; Mayer, C. F. J. Org. Chem. 1969, 34, 2814. anhydrous $\mathrm{MgSO}_{4}$. After evaporation of the solvent in vacuo, $373 \mathrm{mg}(80 \%)$ of diketone $10 \mathrm{a}$ was left

3,3,4,4,5,5-Hexamethylheptane-2,6-dione (10a): mp 67$71^{\circ} \mathrm{C} ;{ }^{1} \mathrm{H}$ NMR $\delta 1.17(\mathrm{~s}, 18 \mathrm{H}), 2.14(\mathrm{~s}, 6 \mathrm{H}) ;{ }^{13} \mathrm{C}$ NMR $\delta 22.54$, $24.51,29.46,45.47,53.97,214.95$; IR $3000,2980,2950,2925$, $1695,1480,1385,1355,1135,1115,1105,1095,965,795 \mathrm{~cm}^{-1}$. Anal. Caled for $\mathrm{C}_{13} \mathrm{H}_{24} \mathrm{O}_{2}$ : C, 73.54; $\mathrm{H}, 11.39$. Found: $\mathrm{C}$, 73.21; H, 11.37.

3,3,4,4,5-Pentamethylheptane-2,6-dione (10b): oil; ${ }^{1} \mathrm{H}$ $\operatorname{NMR}\left(\mathrm{CCl}_{4}\right) \delta 1.08(\mathrm{~s}, 3 \mathrm{H}), 1.12(\mathrm{~d}, J=7 \mathrm{~Hz}, 3 \mathrm{H}), 1.25(\mathrm{~s}, 9$ $\mathrm{H}), 2.10(\mathrm{~s}, 6 \mathrm{H}), 3.05(\mathrm{q}, J=7 \mathrm{~Hz}, 1 \mathrm{H}) ;{ }^{13} \mathrm{C}$ NMR $\delta 14.20$, $20.67,21.74,22.07,22.35,29.45,31.40,41.09,48.92,53.46$, $213.14,215.07$; IR 1720, 1700, 1480, 1360, 1260, 1120, 970 $\mathrm{cm}^{-1}$. Anal. Calcd for $\mathrm{C}_{12} \mathrm{H}_{22} \mathrm{O}_{2}: \mathrm{C}, 72.68 ; \mathrm{H}, 11.19$. Found: C, 72.44; H, 11.32 .

3,3,4,4-Tetramethylheptane-2,6-dione (10c): oil; ${ }^{1} \mathrm{H}$ NMR $\left(\mathrm{CCl}_{4}\right) \delta 1.07(\mathrm{~s}, 6 \mathrm{H}), 1.12(\mathrm{~s}, 6 \mathrm{H}), 2.12(\mathrm{~s}, 3 \mathrm{H}), 2.17(\mathrm{~s}, 3 \mathrm{H})$, $2.50(\mathrm{~s}, 2 \mathrm{H}) ;{ }^{13} \mathrm{C}$ NMR $\delta 21.32,22.45,29.76,33.05,38.49$, $49.12,52.93,209.13,214.81$. Anal. Calcd for $\mathrm{C}_{11} \mathrm{H}_{20} \mathrm{O}_{2}$ : C, 71.70; H, 10.94. Found: C, 71.64; H, 11.17.

Hydrogenation of Ozonide 6a. Ozonide 6a $(1.50 \mathrm{~g}, 6.57$ $\mathrm{mmol}$ ) and $\mathrm{Pd}$ suspended on carbon $(120 \mathrm{mg}$ ) was dissolved in $15 \mathrm{~mL}$ of methanol. Then, the hydrogenation was conducted under a normal pressure at $20^{\circ} \mathrm{C}$ for $30 \mathrm{~min}$. After filtration of $\mathrm{Pd} / \mathrm{C}$, the solvent was evaporated to leave diketone $10 \mathrm{a}$ (1.30 g, $93 \%$ ).

Treatment of a Mixture of Two Ozonides, $6 \mathrm{a}$ and $6 \mathrm{c}$, with $\mathbf{P P h}_{3}$. A THF solution $(20 \mathrm{~mL})$ of $6 \mathrm{a}(19 \mathrm{mg}, 0.085$ $\mathrm{mmol}$ ), 6c (17 mg, $0.083 \mathrm{mmol}$ ), and triphenylphosphine (22 $\mathrm{mg}, 0.084 \mathrm{mmol}$ ) was refluxed for $3 \mathrm{~h}$. After evaporation of the solvent, the residue was separated by column chromatography on silica gel. Elution with ether-hexane (1:20) gave the unreacted ozonide $6 \mathrm{a}(19 \mathrm{mg}, 100 \%)$. Subsequent elution with ether-hexane (1:5) gave diketone $10 \mathrm{c}(15 \mathrm{mg}, 96 \%)$.

Treatment of a Mixture of Two Ozonides, 6a and 6e, with PPhs. A CDCl 3 solution $(0.3 \mathrm{~mL})$ of $6 a(40 \mathrm{mg}, 0.18$ $\mathrm{mmol}$ ) and $6 \mathrm{e}(25 \mathrm{mg}, 0.17 \mathrm{mmol})$ was admixed with $0.2 \mathrm{~mL}$ of a $\mathrm{CDCl}_{3}$ solution containing $\mathrm{PPh}_{3}(46 \mathrm{mg}, 0.18 \mathrm{mmol}$ ) in a NMR tube and kept at $20^{\circ} \mathrm{C}$. After $3 \mathrm{~h}^{1} \mathrm{H}$ NMR analysis showed the disappearance of the signals attributable to $6 \mathrm{e}$ with concomitant appearance of diketone 10e. After $24 \mathrm{~h}$ the crude products were separated by column chromatography on silica gel. The first fraction (elution with ether-hexane, 5:95) contained the unreacted ozonide $6 \mathbf{a}(40 \mathrm{mg}, 100 \%)$. From the second fraction (elution with ether-hexane, 1:1) was obtained diketone $10 \mathrm{e}(10 \mathrm{mg}, 46 \%)$.

Treatment of a Mixture of Two Ozonides, $6 \mathrm{~d}$ and $6 e$, with PPh. A solution of $6 \mathrm{~d}(292 \mathrm{mg}, 1.7 \mathrm{mmol}), 6 e(245 \mathrm{mg}$, $1.7 \mathrm{mmol}$ ), and triphenylphosphine $(450 \mathrm{mg}, 1.7 \mathrm{mmol})$ in benzene $(10 \mathrm{~mL})$ was stirred at $20^{\circ} \mathrm{C}$ for 1 day. After evaporation of the solvent, the crude products were separated by column chromatography on silica gel. Elution with etherhexane $(1: 20)$ gave a ca. $2: 1$ mixture of $6 \mathrm{~d}\left({ }^{1} \mathrm{H}\right.$ NMR $\delta 0.91$ (s, $3 \mathrm{H}), 1.38(\mathrm{~s}, 3 \mathrm{H}))$ and $6 \mathrm{e}\left({ }^{1} \mathrm{H}\right.$ NMR $\left.\delta 1.38(\mathrm{~s}, 6 \mathrm{H})\right)(220 \mathrm{mg})$. Subsequent elution with ether-hexane (15:85) gave a ca. 1:2 mixture of diketones, $10 \mathrm{~d}\left({ }^{1} \mathrm{H}\right.$ NMR $\delta 1.08(\mathrm{~s}, 6 \mathrm{H}), 2.05(\mathrm{~s}, 6$ $\mathrm{H})$ ), and $10 \mathrm{e}\left({ }^{1} \mathrm{H} \mathrm{NMR} \delta 2.05\right.$ (s, $\left.\left.6 \mathrm{H}\right)\right)(195 \mathrm{mg})$.

Theoretical Calculations. The theoretical studies were performed by PM3 molecular orbital method. ${ }^{23}$ The MOPAC program (QCPE No. 455), which was revised as OS/2 Version 5.01 to adapt for the use of a NECPC computer, was obtained through the Japan Chemistry Program Exchange (JCPE) ${ }^{24}$ Final geometries and energetics were obtained by optimizing the total molecular energy with respect to all structural variables.

(23) Stewart, J. J. P. J. Comput. Chem. 1989, 10, 209, 221

(24) Toyoda, J. JCPE News Lett. 1990, $2,37$. 